
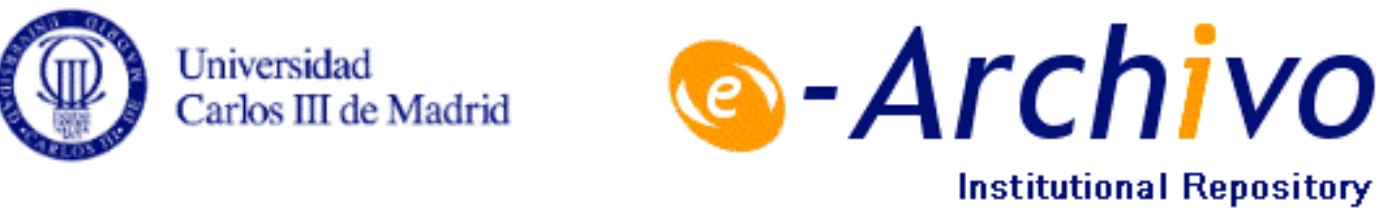

This is a postprint version of the following published document:

Díaz-Giménez, Javier; Prescott, Edward C.; Fitzgerald, Terry; Álvarez, Fernando;. Banking in Computable General Equilibrium Economies. Journal of Economic Dynamics and Control, July-Oct. 1992, vol. 16, n. 3-4, p. 533-559. ISSN 0165-1889. Available in: http://dx.doi.org/10.1016/0165-1889(92)90048-J

(c) Elsevier Science Publishers

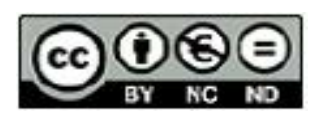

This work is licensed under a Creative Commons Attribution-NonCommercialNoDerivatives 4.0 International License. 


\title{
Banking in computable general equilibrium economies*
}

\author{
Javier Díaz-Giménez \\ Carlos III University, Madrid, Spain
}

\author{
Edward C. Prescott, Terry Fitzgerald, and Fernando Alvarez \\ Unicersity of Minnesota and Federal Reserve Bank of Minneapolis, Minneapolis, MN 55480, USA
}

\begin{abstract}
In this paper we develop a computable general equilibrium economy that models the banking sector explicitly. Banks intermediate between households and between the household sector and the government sector. Households borrow from banks to finance their purchases of houses and they lend to banks to save for retirement. Banks pool households' savings and they purchase interest-bearing government debt and non-interest-bearing reserves. We use this structure to answer two sets of questions: one normative in nature that evaluates the welfare costs of alternative monetary and tax policies, and one positive in nature that studies the real effects of following a procyclical interest-rate policy rule.
\end{abstract}

\section{Introduction}

Existing quantitative general equilibrium models abstract from costly financial intermediation and from the large differences between the average rates at which households and businesses borrow from and lend to banks and other financial intermediaries. ${ }^{1}$ In our opinion, the main reason for this abstraction is not the lack of interest in the quantitative behavior of economies that model the banking sector explicitly, but rather a lack of tools to compute the equilibrium processes of these model economies. These computational difficulties arise because the agent-type heterogeneity needed to model financial intermediation results in a high-dimensional state variable that precludes the use of standard recursive computational methods.

\footnotetext{
* Financial support from the NSF and the Dirección General de Investigación, Ciencia y Tecnología is gratefully acknowledged. The views expressed herein are those of the authors.

${ }^{1}$ Rios-Rull (1990) has a quantitative general equilibrium model with borrowing and lending between generations. There, however, intermediation is costless, so borrowing and lending rates are equal.
} 
Both theoretical and empirical findings motivate our interest in computable economies that model financial intermediation explicitly. On the empirical side, Friedman and Schwartz (1963) have amassed an impressive amount of statistical evidence to support their view that monetary policy shocks can contribute to economic fluctuations and that the contribution of these shocks to U.S. business cycles fluctuations has been important. On the basis of this statistical evidence, Friedman and Schwartz conclude that of the six severe contractions in the U.S. economy after 1867, four involved major disruptions in the banking system. On the theoretical side, some nonquantitative models support Friedman and Schwartz's view that even shocks to the economy that have a small effect on aggregate production possibilities may end up having large aggregate consequences due to their interaction with the financial intermediation sector. Bernanke (1983), Bernanke and Gertler (1989), Greenwood and Williamson (1989), and Williamson (1987) have developed such models. We consider these theoretical papers to be an important first step in the understanding of the interaction between financial intermediation and the business cycle. The obvious next step in this research program is to build quantitative general equilibrium models in which costly financial intermediation is explicitly modeled.

In this paper we develop a computable general equilibrium economy which includes both aggregate uncertainty and an explicit banking sector that intermediates between households and between the household sector and the government sector. Following the neoclassical growth and business cycle tradition, our first step is to see if this structure can be calibrated to U.S. data to mimic selected steady-state observations from the U.S. National Income and Product Accounts (NIPA) and from the Federal Flow of Funds Accounts. If the calibration exercise turns out to be successful, the next step is to use the calibrated economy to answer some quantitative questions about monetary policy issues. One set of these questions is positive in nature and is concerned with determining whether monetary policy shocks have had quantitatively significant effects on real output and employment. The other set of these questions is normative in nature and is concerned with the quantitative evaluation of the costs and benefits of alternative monetary policy arrangements.

Our work builds on İmrohoroğlu (1992), who studies an economy where liquidity-constrained households hold nominal assets as a substitute for insurance against idiosyncratic uncertainty. By varying their holdings of these assets, households buffer their streams of consumption against bad draws of their individual-specific endowment. Her world has a time-invariant interest rate and only one nominal asset, and so no possibility of carrying out open market operations. Díaz-Giménez and Prescott (1992) extend her economy to include large-denomination, interest-bearing government debt; smalldenomination non-interest-bearing currency; and aggregate uncertainty. They 
find that open market operations which result in persistent changes in the inflation rate have significant real effects on output and employment and that these effects are distributed over a multiyear period. Like İmrohoroğlu (1992), Díaz-Giménez and Prescott (1992) abstract from financial intermediation.

In a related paper, İmrohoroğlu and Prescott (1991) introduce a banking technology to intermediate between the household and government sectors. Banks pool households' savings, they purchase large-denomination, interestbearing government debt, and they use the returns to pay interest on households' demand deposits. İmrohoroğlu and Prescott use their model to evaluate the welfare effects of alternative monetary arrangements. (Computational difficulties force them to abstract from capital accumulation, which is a central element of business cycle fluctuations.)

In this paper, we introduce capital accumulation into the household sector. Households borrow to purchase houses, and they save both to hedge themselves against unlucky future times and for retirement. We also model an explicit banking sector that intermediates both between households and between the household sector and the government sector. The rest of the paper is organized as follows. In section 2 we document the importance of the U.S. financial intermediation sector and the borrowing and lending rate differentials faced by U.S. households. In section 3 we describe the model and define the equilibrium processes. The economy is calibrated to U.S. data in section 4. In section 5 we develop a welfare measure based on compensating households for policy changes. Section 6 reports the results of two sets of experiments: one that evaluates the welfare effects of alternative monetary arrangements and another that explores the effects and the desirability of a procyclical interest rate policy. The final section contains some concluding comments.

\section{Financial intermediation: Some facts}

It is a well-known fact that households both borrow from and lend to financial intermediaries and that they do so in sizable amounts. Moreover, it is also well-known - painfully so for many of us - that the average rate paid by households when they borrow is significantly larger than the average rate received by households when they lend. A consequence of these two facts is that both the value added by and the final product of the U.S. financial intermediation sector are significant fractions of total output. Another significant fact is that the contribution of this sector to both the value added and the final product has increased significantly over the last four decades. We now quantify these facts for the U.S. economy.

By households, we mean the decision units that correspond to either individuals or families. These decision units can enter into contracts and own 
Table 1

U.S. household sector balance sheets for selected years. ${ }^{\mathrm{a}}$

\begin{tabular}{|c|c|c|c|}
\hline & \multicolumn{3}{|c|}{ Stock/GNP } \\
\hline & $\overline{1959}$ & 1975 & 1986 \\
\hline Total assets & 3.86 & 3.64 & 4.15 \\
\hline Tangible assets & 1.95 & 2.06 & 2.09 \\
\hline Residential structures & 0.81 & 0.84 & 0.86 \\
\hline Land & 0.52 & 0.54 & 0.63 \\
\hline Plant, equipment, and inventories & 0.24 & 0.31 & 0.24 \\
\hline Consumer durables & 0.38 & 0.37 & 0.36 \\
\hline Debt assets & 1.10 & 1.17 & 1.54 \\
\hline Financial corporate debt & 0.64 & 0.72 & 0.81 \\
\hline Pension fund reserves & 0.17 & 0.27 & 0.48 \\
\hline Nonfinancial corporate debt & 0.09 & 0.08 & 0.07 \\
\hline Government debt & 0.20 & 0.10 & 0.18 \\
\hline Equity assets ${ }^{\mathrm{b}}$ & 0.81 & 0.41 & 0.52 \\
\hline Total liabilities & 0.45 & 0.60 & 0.70 \\
\hline \multicolumn{4}{|l|}{ Owed to } \\
\hline Financial corporations & 0.39 & 0.55 & 0.65 \\
\hline Nonfinancial corporations & 0.05 & 0.04 & 0.04 \\
\hline Government & 0.01 & 0.01 & 0.01 \\
\hline Net worth & 3.41 & 3.04 & 3.45 \\
\hline
\end{tabular}

${ }^{\mathrm{a}}$ Source: Technical appendix I, which is available upon request.

${ }^{b}$ Included is the market value of mutual fund shares (other than money market funds) held by households.

assets, and they make consumption, labor, and saving choices that are constrained by a household-specific budget constraint. Note that this financially based definition of households is significantly different than the one used in the NIPA of most countries. In the NIPA, a household is a unit which consumes goods and services and supplies factors of production to the business sector. The households in our framework, in addition to these activities, produce goods and services. Our household sector, therefore, includes small businesses such as farms, sole proprietorships, and partnerships which the NIPAs include in the unincorporated business sector. In our framework, as in the NIPAs, corporations and government enterprises are not included in the household sector. Tables 1 and 2 present balance sheets for selected years of the household and the corporate sectors for the U.S. economy.

Some points worth noting are the following: First, almost two-thirds of nongovernment tangible assets are owned by the household sector, and only one-third is owned by the corporate sector. Second, owner-used real estate and consumer durables are a large part of household capital: Indeed, they constitute more than two-thirds of the households' tangible assets and over 
Table 2

U.S. corporate sector balance sheet for selected years. ${ }^{a}$

\begin{tabular}{lccc}
\hline & & \multicolumn{3}{c}{ Stock/GNP } & \\
& 1959 & 1975 & 1986 \\
\hline Total assets & 1.76 & 2.05 & 2.24 \\
$\quad$ Tangible assets & 0.97 & 1.06 & 1.02 \\
$\quad$ Residential structures & 0.01 & 0.02 & 0.01 \\
$\quad$ Land & 0.16 & 0.10 & 0.12 \\
$\quad$ Plant, equipment, and inventories & 0.80 & 0.94 & 0.89 \\
Debt assets & 0.79 & 0.99 & 1.22 \\
$\quad$ Household debt held by financial corporations & 0.39 & 0.65 & 0.65 \\
$\quad$ Household debt held by nonfinancial corporations & 0.05 & 0.04 & 0.04 \\
$\quad$ Government debt & 0.35 & 0.30 & 0.53 \\
$\quad$ & & & \\
Total liabilities & 0.96 & 1.12 & 1.44 \\
Owed to households by & & & \\
$\quad$ Financial corporations & 0.81 & 0.99 & 1.29 \\
$\quad$ Nonfinancial corporations & 0.09 & 0.08 & 0.07 \\
Owed to government & 0.06 & 0.05 & 0.08 \\
$\quad$ & & & \\
Net worth & 0.80 & 0.93 & 0.80 \\
$\quad$ Market value of equities held by households & 0.81 & 0.47 & 0.52 \\
Imputed unassigned net liabilities &
\end{tabular}

${ }^{\text {a }}$ Source: Technical appendix $\mathbf{I}$, which is available upon request.

${ }^{b}$ This is the difference between the net worth category and the market value of equities held by households category. We interpret this as representing unmeasured or mismeasured liabilities and assets of corporations.

one-half of the total economy's tangible assets. Owner-occupied housing and consumer durables are the components of capital that we introduce into this exploratory application of the technology developed in this paper for computable general equilibrium analyses of economies with financial intermediation.

We turn now to NIPA data. In table 3, we present the financial intermediary sector's share of the value added by and the final product of the U.S. financial intermediation sector for selected years in the postwar period. From the point of view of our framework, these numbers understate the importance of financial intermediation. The reason that they are underestimated is that some financial intermediary services are used by business in our household sector and therefore are treated as intermediate goods in the NIPA reporting system. For this reason we also report the total product of the financial intermediary sector. These total product numbers overstate the importance of the financial intermediation sector because some of this product is an intermediate good to the corporate sector. Financial intermediation is large: it was between 5 and 7 percent of GNP in the early 1980s. 
Table 3a

U.S. financial sector data in selected years: Value added by subsectors. ${ }^{a}$

\begin{tabular}{lccccc}
\hline & \multicolumn{5}{c}{ Percent of GNP } \\
\cline { 2 - 5 } & 1950 & 1960 & 1970 & 1980 & 1989 \\
\hline $\begin{array}{l}\text { Banking and credit agencies other } \\
\quad \text { than banks }\end{array}$ & 1.3 & 1.7 & 1.8 & 2.1 & 2.7 \\
$\begin{array}{l}\text { Insurance carriers, insurance agents, } \\
\text { brokers, and services }\end{array}$ & 1.2 & 1.6 & 1.5 & 1.8 & 1.9 \\
$\begin{array}{l}\text { Other subsectors } \\
\text { Total finance and insurance sector }\end{array}$ & 0.2 & 0.4 & 0.4 & 0.4 & 0.9 \\
& 2.7 & 3.7 & 3.7 & 4.4 & 5.6
\end{tabular}

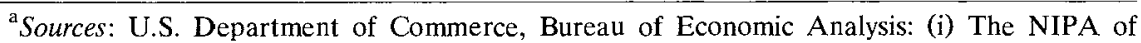
U.S., 1929-82 Statistical Tables; (ii) Survey of Current Business, Vol. 71, 1991: January (No. 1), April (No. 4), July (No. 7), and September 1965 (No. 9); (iii) Staff Papers 29 and 39. For Bad Debt: Statistics of Income, Corporate Income Tax Return, I.R.S., U.S. Department of Treasury, 1958, 1967, 1976, and 1982.

${ }^{\mathbf{b}}$ This includes the categories security commodity brokers, services, and holdings and other investment companies.

${ }^{\mathrm{c}}$ Components may not add to totals due to rounding.

Table 3b

U.S. financial sector data in selected years: Industry product, final product, and bad debt. ${ }^{\text {a }}$

\begin{tabular}{lcccc} 
& \multicolumn{4}{c}{ Percent of GNP } \\
\cline { 2 - 5 } & 1958 & 1967 & 1976 & 1982 \\
\hline Industry product & 5.8 & 5.8 & 6.1 & 7.6 \\
Final product & 2.7 & 3.1 & 3.2 & 4.1 \\
Value-added & 3.2 & 3.2 & 3.1 & 4.0 \\
Bad debt & 0.1 & 0.1 & 0.2 & 0.3
\end{tabular}

${ }^{a}$ Sources: U.S. Department of Commerce, Bureau of Economic Analysis: (i) The NIPA of U.S., 1929-82 Statistical Tables; (ii) Survey of Current Business, Vol. 71, 1991: January (No. 1), April (No. 4), July (No. 7), and September 1965 (No. 9); (iii) Staff Papers 29 and 39. For Bad Debt: Statistics of Income, Corporate Income Tax Return, I.R.S., U.S. Department of Treasury, 1958, 1967, 1976, and 1982.

Table 4 reports, for the United States in 1986, stocks and average interest rates paid on various categories of household borrowing and lending to banks and other financial intermediaries. Even for collateralized mortgage loans, the average interest rate is nearly 4 percent higher than the return on bank certificates of deposit. The spread between borrowing and lending rates increases if the borrowing is in the form of uncollateralized loans and the lending is in the form of deposits on which the household can write checks. In this latter case, the difference is in excess of 10 percent.

Finally, we turn to the U.S. housing sector. Most of this sector's final product is the imputed rent of owner-occupied housing. Table 5 reports the 
Table 4

Selected U.S. household sector borrowing and lending stocks and interest rates, $1986 .^{\mathrm{a}}$

\begin{tabular}{lc}
\hline Borrowing & Stock/GNP \\
\hline Year-end outstanding stocks & \\
Mortgages & 0.60 \\
Consumer credit & 0.16 \\
Bank loans & 0.04 \\
Average net interest rates & $10.2 \%$ \\
New mortgages & \\
New car, 48 months & 14.0 \\
Personal credit, 24 months & 16.5 \\
Credit card & 18.3 \\
Prime rate & 8.3 \\
\hline Lending & Stock/GNP \\
\hline Year-end outstanding stocks & \\
Checkable deposits \& currency & 0.13 \\
Time deposits & \\
U.S. government securities & d \\
Average net interest rates & 0.56 \\
NOW accounts & 0.14 \\
Certificates of deposit, 6 months & $5.0 \%$ \\
U.S. T-bill, 6 months & 6.7 \\
\hline
\end{tabular}

${ }^{a}$ Sources: Board of Governors of the Federal Reserve System: (i) Balance Sheets for the U.S. Economy 1949-90, Flow of Funds, September 1991; (ii) Annual Statistical Digest 1986; (iii) Money Stocks, Liquid Assets and Debt Measures, 1986.

${ }^{b}$ This is an effective rate on conventional mortgage. It includes fees and charges, assuming repayment at the end of ten years.

${ }^{c}$ This includes small and large time deposits and money market fund shares.

${ }^{\mathrm{d}}$ This includes savings bonds, agency issues, and other Treasury issues.

total and the owner-occupied housing sectors imputed rental income statements for 1986. These numbers will be used in the calibration of our model economy to U.S. data.

\section{The model economy}

\subsection{Population dynamics}

Our economy is inhabited by a large number of households at each point in time. Some of these households do not survive to the following period. The number (actually, measure) of new households each period is equal to the number that did not survive from the previous period. Consequently, the population size is constant. At each date $t$, each household is indexed by an idiosyncratic factor $s_{t}$. This factor belongs to a finite set $S=\left\{1,2, \ldots, n_{s}\right\}$. These factors affect a household's consumption possibility set, utility flow 
Table 5

U.S. housing sector profit and loss statement, 1986; values as percent of GNP. ${ }^{a}$

\begin{tabular}{lcc}
\hline & $\begin{array}{c}\text { Owner-occupied } \\
\text { housing sector }\end{array}$ & $\begin{array}{c}\text { Total } \\
\text { housing sector }\end{array}$ \\
\cline { 2 - 3 } Rents $^{\mathrm{b}}$ & $7.2 \%$ & $9.9 \%$ \\
Less maintenance, insurance, and repair $_{\text {Equals value added }}^{c}$ & 1.0 & 1.6 \\
Property taxes $^{\mathrm{c}}$ & 6.1 & 8.3 \\
Depreciation $_{\text {Wages }}$ & 1.2 & 1.4 \\
Interest payments $_{\text {Rental income }}^{\mathrm{d}}$ & 1.6 & 2.3 \\
Corporate profits & - & 0.1 \\
\hline
\end{tabular}

${ }^{\text {a }}$ Sources: Survey of Current Business, July 1990, Vol. 70, No. 7, Table 8.9, p. 101, and Table 1.23 , p. 49.

${ }^{\mathrm{b}}$ For owner-occupied housing sector, imputed rent.

${ }^{c}$ Indirect business tax and nontax liability plus business transfer payments less subsidies plus current surplus of government enterprises.

${ }^{d}$ Rental income of persons plus proprietor's income.

function, and probability of dying. The nature of these stochastic processes will be specified after we have specified the exogenous economy-wide stochastic process, $\left\{z_{t}\right\}$. This process follows a finite state Markov chain with transition probabilities given by

$$
\pi_{z}\left(z^{\prime} \mid z\right)=\operatorname{Pr}\left\{z_{t+1}=z^{\prime} \mid z_{t}=z\right\}
$$

where $z \in Z=\left\{1,2, \ldots, n_{z}\right\}$. We assume that the Markov chain generating $z$ is such that it has a single ergodic set, no transient states, and no cyclically moving subsets.

Each household faces an idiosyncratic random disturbance, $s_{t}$, to its individual production opportunities. Conditional on the realization of the economy-wide shock one period ahead, these idiosyncratic disturbances are assumed to be independent and identically distributed across households. The process for these household-specific production shocks is assumed to follow a finite state Markov chain with conditional transition probabilities given by

$$
\pi_{s}\left(s^{\prime} \mid s, z^{\prime}\right)=\operatorname{Pr}\left(s_{t+1}=s^{\prime} \mid s_{t}=s, z_{t+1}=z^{\prime}\right)
$$

where $s, s^{\prime} \in S=\left\{1,2, \ldots, n_{s}\right\}$ and $z^{\prime} \in Z$.

The state $n_{s}$ is an absorbing state and corresponds to death. We use $\sigma(s)$ to indicate whether or not a person is alive at a point in time. A person is 
alive at $t$ if $\sigma\left(s_{t}\right)=1$ and is dead if $\sigma\left(s_{t}\right)=0$. Therefore, the function $\sigma(s)=0$ for $s=n_{s}$ and $\sigma(s)=1$ for $s<n_{s}$.

The joint processes on each household's idiosyncratic shock, $s$, and on the economy-wide shock, $z$, are therefore Markov chains with $n=n_{s} n_{z}$ states. Their transition probabilities are

$$
\pi\left[\left(s^{\prime}, z^{\prime}\right) \mid(s, z)\right]=\pi_{z}\left(z^{\prime} \mid z\right) \pi_{s}\left(s^{\prime} \mid s, z^{\prime}\right) .
$$

The state space $S \times Z$ of the Markov chain on $(s, z)$ can be partitioned into a finite number of ergodic sets $S_{h} \times Z$ for $h=1, \ldots, n_{h}$ and one transient set $T$. We assume that the chain is such that it has no cyclically moving subsets. The initial measure of agents with $s \in S_{h}$ is $\lambda_{h}$. Given that the probability that $s_{t} \in S_{h}$ is always one, the measure of households of type $h$ is timeinvariant.

\subsection{The government sector}

The government in this economy taxes labor and net interest income at a rate $\theta$. This is a proportional tax and is restricted to be a function of the current value of the economy-wide shock, $z_{t}$, only. The tax rate at date $t$ is $\theta\left(z_{t}\right)$. The government also issues two assets. The first asset bears no interest, and it determines the unit of account. We denote it by $R$, and we call it reserves. The second asset is a riskfree promise to deliver one unit of currency at the beginning of the period immediately after its date of issue. This asset sells at a discount. We denote it by $B$, and we call it a $T$-bill. (Note that throughout this paper we follow the convention that capital letters denote nominal quantities and, except where otherwise indicated, lower-case letters denote the real values of the corresponding variables in terms of currentperiod prices.)

Variable $p_{t}$ is the price of one unit of the date $t$ composite good. Government policy determines the pricing process on reserves, $e_{t}=\varepsilon\left(z_{t}\right)=$ $p_{t+1} / p_{t}$, and the nominal interest rate on government debt, $i_{t}=\iota\left(z_{t}\right)$, where the interest is paid in advance. To implement these policies, the government exchanges goods and currency at a price $p_{t}$ and sells and buys promises to deliver one unit of nominal value next period at price $1-\iota\left(z_{t}\right)$. We only consider economies with a positive nominal interest rate policy, that is, where $\iota(z) \geq 0$ for all $z \in Z$. To induce a demand for the lower-yielding reserves, the government requires banks to keep at least a fraction $\rho_{t}=\rho\left(z_{t}\right)$ of their customers' deposits in reserves. Additional legal constraints preclude households from holding T-bills directly. Only the financial intermediaries have access to the T-bill market. Note that the pricing policies and the reserve requirement policy are also restricted to being a function of the current value of the economy-wide shock, $z_{t}$, only. 
At date $t$, the government makes real transfers to households. The transfer is contingent on the economy-wide shock $z_{t}$ and upon the household's real financial assets, $a_{t}$, its tangible assets, $k_{t}$, and its idiosyncratic shock, $s_{t}$. The transfer policy is $\omega(a, k, s, z)$. Finally, the government taxes households' estates. When a household dies, its estate is liquidated and the proceeds are used to pay off its debts. The remaining assets of the estate, if any, are subject to a 100 percent estate tax.

A government policy rule is, therefore, a specification of $[\varepsilon(z)$, $\iota(z), \theta(z), \rho(z), \omega(a, k, s, z)]$ and the associated processes on government consumption, $g$, on the government supply of T-bills, $B_{g}$, and on the government supply of reserves, $R_{g}$.

\subsection{The banking sector}

Banks play two major roles in our model economies. Their first role is to intermediate between households by making loans to households who want to borrow and by accepting deposits from households who want to lend. Their second role is to intermediate between the household and government sectors, by pooling household savings and buying government-issued interest-bearing debt and non-interest-bearing reserves.

We assume that both the deposit and the lending technologies are freely accessible and that they display constant returns-to-scale. Associated with the deposit technology is a cost, $\eta_{D}$, per unit of value intermediated. Associated with the lending technology is also a cost, $\eta_{L}$, per unit of value loaned. Interest is paid in advance. Given these facts, each period banks solve the following static maximization problem:

$$
\max _{B_{b}, L_{b}, R_{b}, D_{b}} B_{b}+R_{b}+L_{b}-D_{b}
$$

subject to

$$
\begin{aligned}
& B_{b}(1-i)+L_{b}\left(1-i_{L}\right)+R_{b}+\eta_{D} D+\eta_{L} L \leq D_{b}\left(1-i_{D}\right), \\
& R_{b} \geq \rho D_{b}, \\
& L_{b}, R_{b}, D_{b} \geq 0 .
\end{aligned}
$$

Here $B_{b}$ denotes bank purchases of government interest-bearing debt, $L_{b}$ denotes bank loans to the household sector, $R_{b}$ denotes bank holdings of reserves, $D_{b}$ denotes household deposits accepted, and $i_{L}$ and $i_{D}$ denote, respectively, the nominal interest rates on loans and deposits. Constraint (5) is the cash-flow constraint while (6) is the reserve requirement. The objective function is the end-of-period assets of the bank. 
Given that we only consider policies with a positive nominal rate of return on interest-bearing government debt, T-bills dominate reserves in rate of return. Consequently, at an optimum, inequality (6) holds with equality. For optima to exist with strictly positive $D_{b}$ and $L_{b}$, the interest rates must satisfy the following conditions:

$$
\begin{aligned}
& i_{L}=i_{L}(z)=i(z)+\eta_{L}, \\
& i_{D}=i_{D}(z)=[1-\rho(z)] i(z)-\eta_{D} .
\end{aligned}
$$

Perfect competition and constant returns-to-scale imply that equilibrium bank profits are zero. Note also that, from eqs. (8) and (9), we can obtain the difference between the household borrowing and lending rates:

$$
(1-\rho) i_{L}-i_{D}(z)=(1-\rho) \eta_{L}-\eta_{D}
$$

Our model economy has no features that prevent households from defaulting on their loans. To make the lending technology incentive-compatible, banks require collateral for their loans. Effectively, households can only borrow up to the resale value of their end-of-period capital.

\subsection{The household sector}

\subsubsection{Preferences}

Households are only concerned with their future consumption and leisure if they are alive. Consequently, they order their random streams of these goods according to

$$
\mathrm{E} \sum_{t=0}^{\infty} \beta^{t} \sigma\left(s_{t}\right)\left[U_{1}\left(c_{t}, k_{t}^{\prime}, \tau-n_{t}, s_{t}\right)+U_{2}\left(g_{t}\right)\right]
$$

where $U_{1}$ and $U_{2}$ are continuous and strictly concave utility functions, $\beta$ is the time-discount factor, $c_{t}$ is household consumption which is restricted to being nonnegative, $k_{t}^{\prime} \in K=\left\{0,1, \ldots, n_{k}\right\}$ represents the services of the capital goods and consumer durables held by the household during period $t, \tau$ is a household's endowment of productive time, $n_{t}$ is labor, and $g_{t}$ is public per capita consumption. Hence, $\tau-n_{t}$ is time allocated by the household to nonmarket activities, which we call leisure. 


\subsubsection{Productive opportunities}

The household's date $t$ production of the composite good is

$$
w\left(s_{t}, z_{t}\right) n_{t},
$$

where $w(s, z)$ is that household's technology parameter. This composite good can be transformed into consumption, investment, banking services, or capital maintenance services on a one-to-one basis. When they choose to work, agents are paid their marginal product. Therefore, $w(s, z)$ equals the household's real wage. Following Rogerson (1988) and Hansen (1985), we assume labor indivisibility. Hours of labor services provided, $n_{t}$, are constrained to belong to the set $\{0,1\}$. Zero corresponds to not being employed and one to being employed.

\subsubsection{Initial endowments and liquidation of assets}

Households are born with no initial endowment of assets. When their time comes to die, they do so overnight, after the current-period labor, consumption, investment, and savings have taken place. Early the next morning, their estates are liquidated. Their capital goods are transformed into units of the current-period composite good and are sold in the market. The proceeds of this sale are used to pay off the household's loans, if any. Whatever is left over, together with the remainder of the estate, is taxed away.

\subsubsection{Capital maintenance and disinvestment}

We assume that household capital has to be maintained. Each period households incur a cost of $\mu$ units of that period's composite good per unit of capital used during that period. We also assume that there is an irreversibility in the capital accumulation process. When a household decides to sell part of its capital stock, $k>0$ units of capital are transformed into $\phi k$ units of the composite good, where $0<\phi<1$.

\subsubsection{The households' decision problem}

Let $D_{t}$ denote the nominal household deposits, $L_{t}$ the nominal household debt, $A_{t}$ the beginning-of-period nominal asset holdings, and $x_{t}^{d}$ and $x_{t}^{s}$ current-period purchases and sales of investment goods. Then the nominal version of the household competitive decision problem is

The objective function

$$
\max \mathrm{E} \sum_{t=0}^{\infty} \beta^{t} \sigma\left(s_{t}\right) U_{1}\left(c_{l}, k_{t}^{\prime}, \tau-n_{t}, s_{t}\right)
$$


subject to the following constraints, one for each $t=0,1,2, \ldots$ :

\section{Budget Constraint}

$$
\begin{aligned}
& p_{t} c_{t}+p_{t} x_{t}^{\mathrm{d}}+D_{t}+p_{t} \mu k_{t}^{\prime}+T_{t}+i_{L}\left(z_{t}\right) L_{t} \\
& \leq A_{t}+p_{t} w\left(s_{t}, z_{t}\right) n_{t}+p_{t} x_{t}^{\mathrm{s}}+L_{t} \\
& \quad+\iota_{D}\left(z_{t}\right) D_{t}+p_{t} \omega(a, k, s, z),
\end{aligned}
$$

where

$$
T_{t}=\theta\left(z_{t}\right)\left[p_{t} w\left(s_{t}, z_{t}\right) n_{t}+i_{D}\left(z_{t}\right) D_{t}-i_{L}\left(z_{t}\right) L_{t}\right]
$$

\section{Borrowing Constraint}

$$
L_{t} \leq \phi k_{t+1} p_{t+1}
$$

Law of Motion of Wealth

$$
A_{t+1}=D_{t}-L_{t}
$$

\section{Law of Motion of Capital}

$$
k_{t+1}=k_{t}^{\prime}=k_{t}+x_{t}^{\mathrm{d}}-x_{t}^{\mathrm{s}} / \phi .
$$

The maximization is also subject to next period's real financial assets, $A_{t+1} / p_{t+1}$, belonging to the finite set $A,{ }^{2} n_{t}$ belonging to $\{0,1\}$ and $k_{t}^{\prime}$ belonging to the finite set $K$, given $A_{0}$ and $k_{0}$.

Let $d=D_{t} / p_{t}$ denote household real deposits and $l_{t}=L_{t} / p_{t}$ denote household real loans, both valued in terms of the current period's composite good, and let $a_{t}=A_{t} / p_{t}$ denote the beginning-of-period real assets. Then the functional equation for the dynamic program solved by an $(a, k, s)$-type

\footnotetext{
${ }^{2}$ In our model economies, the units of $A$ determine the smallest denomination of household assets. In general, the $A$ units do not coincide with the unit of account. As is true in most modern economies, the unit of account in our model is the unit of denomination of noninterest-bearing government debt. This unit of account, however, need not coincide with the smallest unit of currency issued. In the United States, for example, the unit of account is the dollar while the smallest currency unit is the cent. In other countries, like Italy, the smallest current unit 10 liras, is a multiple of the unit of account, the lira.
} 
household is the following:

$$
\begin{aligned}
v(a, k, s, z)= & \max _{c, n, d, l, x^{\mathrm{d}}, x^{s}, a^{\prime}, k^{\prime}}\left\{\sigma(s) U_{1}\left(c, k^{\prime}, \tau-n, s\right)\right. \\
& \left.+\beta \sum_{s^{\prime}, z^{\prime}} v\left(a^{\prime}, k^{\prime}, s^{\prime}, z^{\prime}\right) \pi\left[\left(s^{\prime}, z^{\prime}\right) \mid(s, z)\right]\right\},
\end{aligned}
$$

subject to

$$
\begin{aligned}
& c+x^{\mathrm{d}}+d+\mu k^{\prime} \leq a+[1-\theta(z)]\left[w(s, z) n+d i_{D}(z)-l i_{L}(z)\right] \\
& +x^{\mathrm{s}}+l+\omega(a, k, s, z) \text {, } \\
& l \leq \phi k^{\prime} e(z), \\
& a^{\prime} \leq(d-l) / e(z), \\
& k^{\prime}=k+x^{\mathrm{d}}-x^{\mathrm{s}} / \phi,
\end{aligned}
$$

and also subject to $a^{\prime} \in A, k^{\prime} \in K, n \in\{0,1\}$, and $a, k$ given. Since the household's problem is a finite-state, discounted dynamic program, an optimal stationary Markov plan always exists.

\subsection{Definition of equilibrium}

In the goods and securities markets, the government is not small, so treating it as just another price-taking agent is not reasonable. Instead, part of the specification of the economy must be the policy arrangement employed. Features of our explicit arrangement include what markets operate and what rules govern banks. Another feature of our policy arrangement is that at each date the government exchanges goods for deposits at price $p_{t}$. Furthermore, these prices satisfy $p_{t+1}=p_{t} \varepsilon\left(z_{t}\right)$. Also, there is a reserve requirement $\rho(z)$ and an income tax rate $\theta(z)$. Finally, the government issues as many T-bills to banks at price $1-\iota(z)$ as they demand. For such arrangements we now define a recursive equilibrium.

The state of a household is the four-tuple $(a, k, s, z)$. The measure of agents of type $(a, k, s)$ is $y(a, k, s)$. We let $y$ denote the corresponding measure. The economy-wide state is the pair $(y, z)$.

An equilibrium for a policy arrangement $\{\varepsilon(z), \iota(z), \theta(z), \rho(z), \omega(a, k, s, z)\}$, given $y_{0}$, consists of six basic parts: a government policy $\left\{g(y, z), b_{g}(y, z)\right.$, $\left.r_{g}(y, z)\right\}$, a household policy $\{c(a, k, s, z), d(a, k, s, z), l(a, k, s, z)$, 
subject to the following constraints, one for each $t=0,1,2, \ldots$ :

\section{Budget Constraint}

$$
\begin{aligned}
& p_{t} c_{t}+p_{t} x_{t}^{\mathrm{d}}+D_{t}+p_{t} \mu k_{t}^{\prime}+T_{t}+i_{L}\left(z_{t}\right) L_{t} \\
& \leq A_{t}+p_{t} w\left(s_{t}, z_{t}\right) n_{t}+p_{t} x_{t}^{\mathrm{s}}+L_{t} \\
& \quad+\iota_{D}\left(z_{t}\right) D_{t}+p_{t} \omega(a, k, s, z),
\end{aligned}
$$

where

$$
T_{t}=\theta\left(z_{t}\right)\left[p_{t} w\left(s_{t}, z_{t}\right) n_{t}+i_{D}\left(z_{t}\right) D_{t}-i_{L}\left(z_{t}\right) L_{t}\right] .
$$

\section{Borrowing Constraint}

$$
L_{t} \leq \phi k_{t+1} p_{t+1}
$$

Law of Motion of Wealth

$$
A_{t+1}=D_{t}-L_{t}
$$

Law of Motion of Capital

$$
k_{t+1}=k_{t}^{\prime}=k_{t}+x_{t}^{\mathrm{d}}-x_{t}^{\mathrm{s}} / \phi .
$$

The maximization is also subject to next period's real financial assets, $A_{t+1} / p_{t+1}$, belonging to the finite set $A,{ }^{2} n_{t}$ belonging to $\{0,1\}$ and $k_{t}^{\prime}$ belonging to the finite set $K$, given $A_{0}$ and $k_{0}$.

Let $d=D_{t} / p_{t}$ denote household real deposits and $l_{t}=L_{t} / p_{t}$ denote household real loans, both valued in terms of the current period's composite good, and let $a_{t}=A_{t} / p_{t}$ denote the beginning-of-period real assets. Then the functional equation for the dynamic program solved by an $(a, k, s)$-type

\footnotetext{
${ }^{2}$ In our model economies, the units of $A$ determine the smallest denomination of household assets. In general, the $A$ units do not coincide with the unit of account. As is true in most modern economies, the unit of account in our model is the unit of denomination of noninterest-bearing government debt. This unit of account, however, need not coincide with the smallest unit of currency issued. In the United States, for example, the unit of account is the dollar while the smallest currency unit is the cent. In other countries, like Italy, the smallest current unit 10 liras, is a multiple of the unit of account, the lira.
} 
$\left.n(a, k, s, z), x^{\mathrm{d}}(a, k, s, z), x^{\mathrm{s}}(a, k, s, z), a^{\prime}(a, k, s, z), k^{\prime}(a, k, s, z)\right\}$, a banking policy $\left\{b_{b}(y, z), l_{b}(y, z), r_{b}(y, z), d_{b}(y, z)\right\}, z$-contingent interest rates $\left\{i_{D}(z), i_{L}(z), i(z)\right\}$, an inflation rate process $e(z)$, and a law of motion for the measures of agent types $y_{a^{\prime} k^{\prime} s^{\prime}}^{\prime}=f_{a^{\prime} k^{\prime} s^{\prime}}\left(y, z, z^{\prime}\right)$ such that:

(i) Given the process on $i_{D}(z), i_{L}(z), e(z)$, and $\theta(z)$, the household policy solves the household's optimization program described in eqs. (19)-(23) above.

(ii) Given the process on $i(z), i_{L}(z), i_{D}(z)$, and $\rho(z)$, the banking policy solves the banking maximization program described in eqs. (4)-(7) above.

(iii) The goods market clears:

$$
\begin{aligned}
& \sum_{a, k, s} y(a, k, s)\left[c(a, k, s, z)+x^{\mathrm{d}}(a, k, s, z)+d(a, k, s, z) \eta_{D}\right. \\
& \left.\quad+l(a, k, s, z) \eta_{L}+\mu k^{\prime}(a, k, s, z)\right]+g(y, z) \\
& =\sum_{a, k, s} y(a, k, s)\left[n(a, k, s, z) w(s, z)+x^{\mathrm{s}}(a, k, s, z)\right],
\end{aligned}
$$

for all $(y, z)$ in the support of the distribution of $\left(y_{t}, z_{t}\right)$ for some $t$.

(iv) The asset markets clear:

$$
\begin{aligned}
& b_{b}(y, z)=b_{g}(y, z), \\
& l_{b}(y, z)=\sum_{a, k, s} y(a, k, s) l(a, k, s, z), \\
& r_{b}(y, z)=r_{g}(y, z), \\
& d_{b}(y, z)=\sum_{a, k, s} y(a, k, s) d(a, k, s, z) .
\end{aligned}
$$

(v) Household and aggregate behavior are consistent:

$$
\begin{aligned}
& f_{a^{\prime} k^{\prime} s^{\prime}}\left(y, z, z^{\prime}\right) \\
& =\sum_{a, k, s \in A\left(a^{\prime}, k^{\prime}, z\right)} y(a, k, s) \pi\left[\left(s^{\prime}, z^{\prime}\right) \mid(s, z)\right]+\psi_{a^{\prime} k^{\prime} s^{\prime}},
\end{aligned}
$$


where

$$
\begin{aligned}
& A\left(a^{\prime}, k^{\prime}, z\right) \\
& =\left\{(a, k, s): \quad a^{\prime}=[d(a, k, s, z)-l(a, k, s, z)] / e(z),\right. \\
& k^{\prime}=k(a, k, s, z)+x^{\mathrm{d}}(a, k, s, z) \\
& \left.-x^{\mathrm{s}}(a, k, s, z) / \phi\right\},
\end{aligned}
$$

and where $\psi$ specifies the measure of types for the newborn. In our world, all the mass of $\psi$ is on $\left(a^{\prime}, k^{\prime}\right)$ pairs for which $a^{\prime}=k^{\prime}=0$, and the total measure of those who are born is equal to the measure of those who die.

(vi) The behavior of endogenous variables is consistent with the policy arrangement. For our class of policy arrangements, this requires $e(z)=$ $\varepsilon(z), i(z)=\iota(z)$, and $g(y, z) \geq 0$ for all $(y, z)$ in the support of the distribution of $\left(y_{t}, z_{t}\right)$ for some $t$.

For the set of policy arrangements that we consider, there is at most one equilibrium. The computational procedure we use to find the equilibrium is to first solve the household problem, which is a finite-state discounted dynamic program, and then use (24) to determine $g(y, z)$. If the $g_{t}=g\left(y_{t}, z_{t}\right)$ is a positive stochastic process, we have found the unique equilibrium given the policy arrangement. Otherwise, we have established that no equilibrium exists for that policy arrangement. (Technical appendix II, which is available upon request, describes in considerable detail our computation procedure.)

\section{Calibration}

Without aggregate uncertainty, the equilibrium path of our model economy converges to a unique steady state with a fixed distribution of households as indexed by their individual state $(a, k, s)$. Steady-state interest rates, aggregate stocks, and aggregate flows are constant. We calibrate our economy so that selected steady-state statistics are close to the corresponding statistics for the U.S. economy in the post-Korean War period.

\subsection{Model period}

We want to match some model statistics with quarterly data, so we select our model period so that a quarter of a year is an integer multiple of a model period. Because we want some temporal aggregation and computational costs 
increase with the number of model periods per year, we select the model period to be one-eighth of a year.

\subsection{Government policy}

We select a nominal return on government debt of 5 percent (annually), an inflation rate of 4 percent, a reserve requirement of 1 percent, and an income tax rate of 0.20 . With these numbers the before-tax real return on government debt is 1 percent, which is in line with the U.S. historical average. Retired households who have no assets receive welfare payments equal to about one-sixth of the average earnings of the working-age population.

\subsection{Banking technology}

We calibrate to a nominal interest rate on deposits of 4 percent and a nominal loan rate of 9.5 percent. These interest rates, along with the policy parameters, imply the $\eta_{D}$ and $\eta_{L}$ parameter values.

\subsection{Population dynamics}

For borrowing and lending to reach the desired level, we introduce a retirement state $s=3$, as well as two working-age states $s=1$ and $s=2$. State $s=1$ corresponds to the productivity of that household's labor time being high; state $s=2$ corresponds to productivity of that household's labor time being low. Productivity in state 2 is 32 percent of the productivity in state 1 . We think of state $s=2$ as corresponding to a minimum-wage job opportunity.

The working life of an individual is geometrically distributed, with an expected duration of 33 years. The retirement life of our individuals is also geometrically distributed. The expected duration of retirement is 10 years. State $s=4$ corresponds to death. Each period, the measure of those who are born is equal to the measure of those who die. As a result, total population is constant.

Following Imrohoroğlu (1992), we select the transition probabilities between states 1 and 2 to be such that the expected time a worker spends in state $s=2$ is three model periods, and the expected time a worker spends in state $s=1$ is 27 model periods. This implies that, each period of time, 90 percent of the workers have the high productivity parameter and 10 percent the low productivity parameter. These parameter values produce annual income fluctuations of household labor income of the magnitude reported in U.S. household surveys. For newborns, the probability of being type $s=1$ is 0.9 and that of being type $s=2$ is 0.1 . 


\subsection{Household preferences for private consumptions}

The set of possible housing stocks is $K=\{0,3\}$. A household with $k=3$ corresponds to a family owning a house with a value three times its annual income. This ratio is twice as large as the typical ratio for U.S. households. The reason we select this larger number is that we want the model's household capital stock to match the U.S. household capital stock, which includes consumer durables and small business capital.

For workers $(s=1$ or $s=2)$ with $k=3$, the utility function of private consumption is

$$
U_{1}(c, 3, n, s)=\left[c^{\alpha-\alpha_{k}} k^{\alpha_{k}}(\tau-n)^{1-\alpha}\right]^{1-\psi} /(1-\psi) .
$$

We select $\tau=2.22$ so that $n=1$ corresponds to people working, including commuting, 45 hours of the 100 weekly hours of productive time. The parameter $\alpha$ is selected so that this 45 hour workweek is near the optimal one. [See Kydland and Prescott (1991).] The $\alpha_{k}$ is selected so that $k=3$ would be optimal if the household rented housing services at a rate equal to the sum of the real after-tax interest rate on borrowing and the maintenance and operations cost. This maintenance and operating cost $\mu$ is set to 0.05 .

Workers $(s=1$ or $s=2)$ who have no capital $(k=0)$ can transform the composite good at rate $1 / \gamma$ into housing services. Their indirect utility is

$$
U_{1}(c, 0, n, s)=\max \left[c_{1}^{\alpha-\alpha_{k}} c_{2}^{\alpha_{k}}(\tau-n)^{1-\alpha}\right]^{1-\psi} /(1-\psi),
$$

subject to

$$
c_{1}+\gamma c_{2} \leq c .
$$

We select $\gamma$ equal to twice the sum of the real borrowing rate and the maintenance cost $\mu=0.05$. This $\gamma$ is sufficiently large that owning a house dominates renting housing services, so households purchase a house as soon as they have enough savings for the required down payment.

Retirees have productivities $w(3, z)=0$. As a result, their wage rate is zero, and they select $n=0$. Their utility function is simply

$$
U_{1}(c, k, n, s)=\delta_{r}\left[c^{\alpha}\right]^{1-\psi} /(1-\psi)
$$

The larger is the parameter $\delta_{r}$, the more important is consumption during retirement relative to consumption during the working period of a person's life. Hence, the larger is $\delta_{r}$, the higher is the equilibrium saving for retirement. The parameter $\delta_{r}$ is selected so that aggregate deposits at banks match U.S. data. 
Table 6a

Calibrated household parameters.

\begin{tabular}{|c|c|c|}
\hline Parameter & & Value \\
\hline \multicolumn{3}{|l|}{ Preferences } \\
\hline Private consumption share & $\alpha$ & 0.3330 \\
\hline Capital service share & $\alpha_{k}$ & 0.1080 \\
\hline Risk aversion & $\psi$ & 4.0000 \\
\hline Time discount factor & $\beta$ & 0.9994 \\
\hline Public consumption constant & $\delta_{g}$ & 0.0104 \\
\hline Productive time & $\tau$ & 2.2200 \\
\hline Retirees' constant & $\delta_{r}$ & 0.2100 \\
\hline \multicolumn{3}{|l|}{ Technology } \\
\hline Maintenance cost & $\mu$ & 0.0500 \\
\hline Rental service coefficient & $\gamma$ & 0.0270 \\
\hline Disinvestment cost & $1-\phi$ & 0.1000 \\
\hline Real wage: State 1 & $w(1, z)$ & 0.1250 \\
\hline State 2 & $w(2, z)$ & 0.0400 \\
\hline Probability of newborn being: Type 1 & $\psi_{1}$ & 0.9000 \\
\hline Type 2 & $\psi_{2}$ & 0.1000 \\
\hline
\end{tabular}

Table 6b

Calibrated bank and government parameters.

\begin{tabular}{lcc}
\hline Parameter & & Value \\
\hline Per unit banking costs & & \\
$\quad$ Deposits & $\eta_{D}$ & 0.0011875 \\
$\quad$ Loans & $\eta_{L}$ & 0.0056250 \\
Government policy & $\rho(z)$ & 0.01000 \\
Reserve requirement & $\theta(z)$ & 0.20000 \\
Tax rate on labor \& interest income & $\iota(z)$ & 0.00625 \\
Nominal interest rate on T-bills & $\varepsilon(z)$ & 1.00500 \\
Inflation rate process & $\omega(0,0,3, z)$ & 0.02000 \\
Welfare transfers to: & $\omega(a, k, s, z)$ & 0.00000 \\
$\quad$ Indigent retirees & & \\
$\quad$ Others & &
\end{tabular}

Table $6 \mathrm{c}$

Calibrated household idiosyncratic shock transition probabilities.

\begin{tabular}{llllll}
\hline & \multicolumn{4}{c}{ To next period, state $s^{\prime}$} \\
From this period, state $s$ & & & & 3 & 4 \\
\hline Working age & & & & & \\
$\quad$ High productivity & 1 & 0.9593 & 0.0369 & 0.0038 & 0.0000 \\
$\quad$ Low productivity & 2 & 0.3317 & 0.6645 & 0.0038 & 0.0000 \\
Retired & 3 & 0.0000 & 0.0000 & 0.9869 & 0.0131 \\
Dead & 4 & 0.0000 & 0.0000 & 0.0000 & 1.0000 \\
\hline
\end{tabular}


Table $7 \mathrm{a}$

Calibrated economy's steady-state balance sheet data.

\begin{tabular}{lc}
\hline & Stock/GNP \\
\hline Household sector & \\
Tangible capital & 2.71 \\
Deposits & 1.01 \\
Loans & 0.46 \\
Net worth & 3.26 \\
Government sector & \\
Reserves & 0.01 \\
Debt & 0.54 \\
\hline
\end{tabular}

Table $7 \mathrm{~b}$

Calibrated economy's steady-state NIPA data.

\begin{tabular}{lr}
\hline & Percent of GNP \\
\hline Value added by sectors & 15.74 \\
Housing & 3.01 \\
Banking & 81.25 \\
Goods producing & \\
Products & 82.61 \\
Consumption & 50.29 \\
Goods & 29.30 \\
Housing & 13.56 \\
Maintenance & 3.10 \\
Banking services & 16.55 \\
Government purchases & 0.84 \\
Investment & \\
\hline
\end{tabular}

The one household preference parameter which turns out to be of small importance is $\psi$, the risk aversion parameter. Following Auerbach and Kotlikoff (1987), we pick $\psi=4$. Results for $\psi=8$ are similar.

\subsection{Household preference for public consumption}

All living households value public consumption by

$$
U_{2}(g)=\delta_{g} g^{\alpha(1-\psi)} /(1-\psi) \text {. }
$$

The parameter $\delta_{g}$ is selected so that half of the population prefers a higher tax rate $\theta$ and the associated higher $g$ and the other half of the population prefers a lower $\theta$ and the associated lower $g$.

These considerations lead us to choose the parameter values listed in table 6 . The steady-state statistics for our calibrated economy are reported in table 7. These statistics are of the same order of magnitude as those for the U.S. economy seen in tables 1 and 2 . 


\section{Measure of welfare benefits}

Now we develop a measure of the welfare benefits associated with switching from one policy to another. This measure is based on the compensation principle - that is, the sum of how much households must be compensated for them to be indifferent between the current policy with the compensation and the new policy without the compensation. In the section, we use $\pi$ to denote the $z$-contingent policy rules $\pi=\{\varepsilon(\cdot), \iota(\cdot), \rho(\cdot), \theta(\cdot), \omega(\cdot)\}$.

We define the total wealth $W$ of a household to be the sum of the values of its financial assets, $a$, its tangible capital, $\dot{k}$, and its human capital, $h$ :

$$
W(a, k, s, z)=a+k+h(s, z)
$$

We define the human capital of a household to be the expected discounted value of the household's labor endowment where we use discount factor $\beta$. Thus,

$$
h(s, z)=\mathrm{E}\left\{\sum_{t} \beta^{t} \sigma\left(s_{t}\right) w\left(s_{t}, z_{t}\right) \mid s_{0}=s, z_{0}=z\right\}
$$

The reason we use discount factor $\beta$ is that our model world does not have a single market discount factor because borrowing and lending rates differ. We say a household's wealth is scaled by factor $\lambda>0$ if that household's $a_{0}$, and $k_{0}$ and all its $w\left(s_{t}, z_{t}\right)$ are scaled by factor $\lambda$.

Let $v_{2}$ denote a household's utility value of the public consumptions process given that the current policy is $\pi$ and the current economy state is $(y, z)$. The expression for $v_{2}$ is

$$
v_{2}(s, y, z \mid \pi) \equiv \mathrm{E}\left\{\sum_{t} \beta^{t} \sigma\left(s_{t}\right) \delta_{g} g_{t}^{\alpha(1-\psi)} /(1-\psi) \mid y_{0}=y, z_{0}=z, \pi\right\} .
$$

A household's total utility, which includes the value of both private and public consumptions, is

$$
V(a, k, s, y, z \mid \pi)=v_{1}(a, k, s, z \mid \pi)+v_{2}(s, y, z \mid \pi),
$$

where $v_{1}$ is the household's optimal value function $v$ with the policy argument $\pi$ made explicit. 
For our structure, if the wealth of every household and the welfare payments $\omega$ are scaled by the factor $\lambda$, the total utility of every household is scaled by the factor $\lambda^{\alpha(1-\psi)}$. For the $v_{1}$ part of $V$, this follows immediately from the household's maximization problem (13)-(18). (Note that the integer constraints must be modified from $k \in K$ to $k / \lambda \in k$ and from $a \in A$ to $a / \lambda \in A$.) For the $v_{2}$ part of $V$, this result follows because the scaling results in the equilibrium $\left\{g_{t}\right\}$ process being scaled by $\lambda$ given that the resource balance constraint (24) must hold.

Let $\pi_{0}$ denote current policy, $(y, z)$ the current aggregate state, and $\pi_{1}$ the alternative policy being evaluated. The compensation factor $\lambda$ is

$$
\lambda\left(\cdot \mid \pi_{0}, \pi_{1}\right)=\left[V\left(\cdot \mid \pi_{1}\right) / V\left(\cdot \mid \pi_{0}\right)\right]^{1 / \alpha(1-\psi)} .
$$

A household's benefits of switching from policy $\pi_{0}$ to $\pi_{1}$ is the product of its $(\lambda-1)$ times its wealth $W$.

Our welfare measure $M$ is benefits summed over all households alive at that point in time divided by wealth summed over all these households. Thus,

$$
\begin{aligned}
& M\left(y, z, \pi_{0}, \pi_{1}\right) \\
& =\frac{\sum_{a, k, s} W(a, k, s, z)\left[\lambda\left(a, k, s, y, z \mid \pi_{0}, \pi_{1}\right)-1\right] y(a, k, s)}{\sum_{a, k, s} W(a, k, s, z) y(a, k, s)} .
\end{aligned}
$$

If negative, benefits are interpreted as costs. This welfare measure can be thought of as corresponding to the benefit of a fractional GNP change that persists forever and that is of magnitude $M$.

An issue is how much of our welfare measure $M$ is due to changes in private consumptions and how much is due to changes in public consumptions. We allocate a fraction

$$
\frac{v_{1}\left(\pi_{1}\right)-v_{1}\left(\pi_{0}\right)}{V\left(\pi_{1}\right)-V\left(\pi_{0}\right)}
$$

to private consumptions and a fraction

$$
\frac{v_{2}\left(\pi_{1}\right)-v_{2}\left(\pi_{0}\right)}{V\left(\pi_{1}\right)-V\left(\pi_{0}\right)}
$$

to public consumptions. Summing private consumption benefits over all households and dividing by total wealth yields a private benefit welfare 
Table 8

Benefits of switching to a policy of a zero after-tax real return on deposits.

\begin{tabular}{lccccccc}
\hline \multirow{2}{*}{$\begin{array}{l}\text { Current after-tax } \\
\text { real return on } \\
\text { deposits }\end{array}$} & \multicolumn{5}{c}{ Senefits as percent of wealth } \\
\cline { 2 - 6 } \cline { 5 - 8 } & $S$ & $S_{1}$ & $S_{2}$ & & \multicolumn{4}{c}{ Our measure } \\
\hline$-2.0 \%$ & 0.20 & 2.62 & -2.42 & & 0.18 & 0.57 & -0.39 \\
-4.0 & 0.41 & 2.99 & -2.58 & & 0.36 & 1.08 & -0.71 \\
-6.0 & 0.63 & 3.42 & -2.79 & 0.56 & 1.55 & -0.99 \\
\hline
\end{tabular}

measure $M_{1}$. Following the analogous procedure for public consumption benefits yields welfare measure $M_{2}$ for public benefits. The sum of $M_{1}$ and $M_{2}$ is $M$.

Our welfare measure differs from the one used previously in general equilibrium evaluations of alternative monetary arrangements [İmrohoroğlu (1992) and İmrohoroğlu and Prescott (1991)]. The measure used in those evaluations compares across steady states; transitional dynamics associated with switching from one policy to another are ignored. We wonder whether the conclusion of these studies would be altered if they used our measure, which takes into consideration the transitional dynamics.

To investigate that, we consider the version of our structure which is essentially the same as that used by Imrohoroğlu and Prescott (1991). This version is constructed as follows. We drop capital from the analysis, prohibit borrowing from banks, and give households infinite life. The preference parameters are $\alpha=0.33, \beta=0.96, \psi=4.0, \tau=2.22$, and $\delta_{g}=0.039111$. There are two $s$ states and no aggregate uncertainty. The values of the productivities are $w(1)=1.0$ and $w(2)=0.4$, and the transition probabilities are $\pi\left(s^{\prime}=1 \mid s=1\right)=0.9565$ and $\pi\left(s^{\prime}=2 \mid s=2\right)=0.50$. Intermediation costs are zero.

The policies we evaluate have a 100 percent reserve requirement, so $\rho=1.0$. The income tax rate is $\theta=0.20$. Policies differ only in their inflation rate. Imrohoroğlu and Prescott (1991) found that the feature of a monetary arrangement that matters for welfare is the arrangement's after-tax real return on liquid assets. For the policy arrangements considered here, the equilibrium after-tax real return is just the negative of the inflation rate.

Table 8 reports the benefits of increasing the after-tax real return on savings for both our measure, which takes into consideration transitional dynamics, and for the steady-state measure, which is denoted by $S$. We find that total benefits for the two measures are quite close, but the contributions of changes in public and private consumptions are quite different. In worlds with capital accumulation, we would expect significant differences in the 
Table 9

Welfare benefits of switching to a policy of less-negative after-tax real return on deposits.

\begin{tabular}{lccccccc}
\hline \multicolumn{2}{c}{ Current policy } & & \multicolumn{2}{c}{ New policy } & & \multicolumn{2}{c}{$\begin{array}{c}\text { Benefits } \\
\text { (percent of wealth) }\end{array}$} \\
$\begin{array}{l}\text { Inflation } \\
\text { rate }\end{array}$ & $\begin{array}{c}\text { After-tax } \\
\text { real return }\end{array}$ & $\begin{array}{c}\text { Inflation } \\
\text { rate }\end{array}$ & $\begin{array}{c}\text { After-tax } \\
\text { real return }\end{array}$ & & Total & Private & Public \\
\hline $4 \%$ & $-0.7 \%$ & $4 \%$ & $-0.7 \%$ & & - & - \\
5 & -1.6 & 4 & -0.7 & & 2.00 & 0.90 & 1.10 \\
6 & -2.5 & 4 & -0.7 & 3.58 & 1.29 & 2.29 \\
\hline
\end{tabular}

measures of total benefits if the policy change significantly altered the amount of capital held.

\section{Experiments}

\subsection{Experiment I: Welfare effects of alternative monetary arrangements}

Motivation: Does including capital accumulation with household borrowing and lending affect the welfare evaluation of alternative monetary arrangements? In particular, will the welfare analysis of arrangements with differing after-tax real returns on deposits yield results similar to those reported in table 8 ?

Description of experiment: For our calibrated economy, we estimate the benefits of increasing the after-tax real return on deposits. This is done by considering alternative arrangements with different inflation rates. Except for the inflation rate, the specification of the model economies is identical to that of the calibrated economy.

Finding: The welfare benefits of switching to a policy with a less-negative after-tax real return are reported in table 9 . The finding is that the benefits of a less-negative after-tax real return on deposits is greater with household borrowing to finance capital accumulation than without it.

\subsection{Experiment II: Effects of alternative stabilization policies}

Motivation: Does a procyclical real interest rate policy stabilize the economy, and is such a policy welfare-improving?

Description of experiment: The calibrated economy is modified by introducing aggregate productivity shocks. In particular, there are two values of the aggregate shock $z$, and the household shock processes are independent of $z$. Compared to the calibrated economy, the modified economy has household productivities that are 2 percent higher when $z=1$ and 2 percent 
lower when $z=2$. Thus, $w(s, z)$ has the following structure for this experiment: $w(1,1)=0.1275, w(1,2)=0.1225, w(2,1)=0.0408$, and $w(2,2)=0.0392$. The probability that $z$ does not change is 0.9286 for each state. The average duration in a state is therefore 14 periods, or 7 quarters. Thus, the average duration of a cycle is 3.5 years, which is the average length of U.S. business cycles.

We consider three real interest rate policies. The benchmark policy uses the policy arrangement of the calibration section. Here the real interest rate on government debt is fixed at 1 percent independent of $z$. The procyclical policy sets the real interest rate at 2 percent when $z=1$ and at 0 percent when $z=2$. The countercyclical policy sets the real interest rate at 0 percent when $z=1$ and at 2 percent when $z=2$. The procyclical and countercyclical policies are obtained by changing the nominal interest rate on government debt in the benchmark policy.

Findings: We find that a procyclical real interest rate policy neither stabilizes the economy, nor significantly improves welfare. Switching from the benchmark policy to the procyclical policy increases fluctuations in output from 1.242 percent to 1.245 percent. [The measure of fluctuations is the standard deviation of data which has been logged and then detrended using the Hodrick-Prescott method as in Kydland and Prescott (1990).] We also find that switching from the benchmark policy to the countercyclical policy increases fluctuations in output from 1.242 percent to 1.272 percent. Switching to the procyclical policy results in a welfare gain of about 0.01 percent of wealth, while switching to the countercyclical policy results in a welfare loss of about 0.17 percent.

\section{Concluding comments}

In this paper, we develop a computable general equilibrium economy that models the banking sector explicitly. Banks intermediate between households and between the household sector and the government sector. Households borrow from banks to finance their purchases of houses, and they lend to banks to save for retirement. Banks pool households savings, and they purchase interest-bearing government debt and non-interest-bearing reserves. We use this structure to answer two sets of questions - one positive in nature that studies the real effects of following a procyclical interest-rate policy rule and one normative in nature that evaluates the welfare costs of alternative monetary and tax policies.

From the answers to the first set of questions, we find that following a policy that results in a procyclical real rate of return on government debt neither stabilizes the economy nor affects welfare significantly. From the answers to the second set of questions, we find that the welfare benefits of policies that increase the after-tax real return on household savings are very 
large. These benefits are as large as the Jorgenson and Yun (1990) estimate of the benefits of the 1984 tax reform and the Lucas (1990) estimate of the benefits resulting from the total elimination of capital taxation. We conclude that for the purposes of evaluating the welfare gains of monetary and tax policies, financial intermediation is important and it should be modeled explicitly.

These findings indicate that there is much to be learned from the explicit modeling of financial intermediation. Two further explorations within this general framework are the following: Our findings suggest that the life cycle plays an important role in issues related to financial intermediation. In fact, in our model economy, most of the lending is accounted for by old households who save for retirement, and most of the borrowing is accounted for by young households who go into debt to finance their purchases of new houses. Incorporating the life cycle explicitly into this class of worlds should be a feasible extension of this line of research, even though the computational costs will rise significantly.

Another natural extension of this line of research is to model entrepreneurs. Their inclusion in this type of model should increase total borrowing significantly. The data reported in section 3 establish that the unincorporated businesses own a large stock of capital and that this capital is financed by borrowing as well as by owners' equity. Like the life-cycle extension, including entrepreneurs that purchase both capital and labor services into these model economies is conceptually straightforward but computationally expensive. Yet a model economy that includes both of these features would provide a significantly better framework for monetary and fiscal policy evaluation than the models currently available.

\section{References}

Auerbach, Alan J. and Laurence J. Kotlikoff, 1987, Dynamic fiscal policy (Cambridge University Press, Cambridge).

Bernanke, Ben S., 1983, Nonmonetary effects of the financial crisis in the propagation of the Great Depression, American Economic Review 73, 257-276.

Bernanke, Ben S. and Mark Gertler, 1989, Agency costs, net worth, and business fluctuations, American Economic Review 79, 14-31.

Díaz-Giménez, Javier and Edward C. Prescott, 1992, Liquidity constraints in economies with aggregate fluctuations: A quantitative exploration, Research Department staff report no. 149 (Federal Reserve Bank of Minneapolis, Minneapolis, MN).

Friedman, Milton and Anna Jacobson Schwartz, 1963, A monetary history of the United States, 1867-1960 (Princeton University Press, Princeton, NJ).

Greenwood, Jeremy P. and Stephen D. Williamson, 1989, International financial intermediation and aggregate fluctuations under alternative exchange rate regimes, Journal of Monetary Economics 23, 401-431.

Hansen, Gary D., 1985, Indivisible labor and the business cycle, Journal of Monetary Economics $16,309-327$

İmrohoroğlu, Ayşe, 1992, The welfare cost of inflation under imperfect insurance, Journal of Economic Dynamics and Control 16, 79-91. 
İmrohoroğlu, Ayşe and Edward C. Prescott, 1991, Evaluating the welfare effects of alternative monetary arrangements, Federal Reserve Bank of Minneapolis Quarterly Review 15, Summer, 3-10.

Jorgenson, Dale W. and Kun Young Yun, 1990, Tax reform and U.S. economic growth, Journal of Political Economy 98, 151-193.

Kydland, Finn E. and Edward C. Prescott, 1990, Business cycles: Real facts and a monetary myth, Federal Reserve Bank of Minneapolis Quarterly Review 14, Spring, 3-18.

Kydland, Finn E. and Edward C. Prescott, 1991, Hours and employment variation in business cycle theory, Economic Theory 1,63-81.

Lucas, Robert E., Jr., 1990, Supply-side economics: An analytical review, Oxford Economic Papers 42, 293-316.

Rios-Rull, Victor, 1990, Is the existence of complete contingent markets for aggregate uncertainty quantitatively important?, Working paper (Carnegie Mellon University, Pittsburgh, PA).

Rogerson, Richard, 1988, Indivisible labor, lotteries, and equilibrium, Journal of Monetary Economics 21, 3-16.

Williamson, Stephen D., 1987, Financial intermediation, business failures, and real business cycles, Journal of Political Economy 95, 1196-1216. 